\title{
Self/image: reading the visual in Atwood's fictive autobiographies
}

Article

Accepted Version

Davies, M. (2017) Self/image: reading the visual in Atwood's fictive autobiographies. Contemporary Women's Writing, 11 (3). pp. 373-390. ISSN 1754-1476 doi:

https://doi.org/10.1093/cww/vpx021 Available at https://centaur.reading.ac.uk/75847/

It is advisable to refer to the publisher's version if you intend to cite from the work. See Guidance on citing.

Published version at: https://academic.oup.com/cww/article/doi/10.1093/cww/vpx021/4454801/Selflmage-Reading-theVisual-in-Atwoods-Fictive?guestAccessKey=97caef4a-48b1-478b-9fa9-67b7b39136c3

To link to this article DOI: http://dx.doi.org/10.1093/cww/vpx021

Publisher: Oxford University Press

All outputs in CentAUR are protected by Intellectual Property Rights law, including copyright law. Copyright and IPR is retained by the creators or other copyright holders. Terms and conditions for use of this material are defined in the End User Agreement.

www.reading.ac.uk/centaur

\section{CentAUR}

Central Archive at the University of Reading 
Reading's research outputs online 


\title{
Self/Image: Reading the Visual in Atwood's Fictive Autobiographies
}

\author{
Madeleine Davies
}

\begin{abstract}
Margaret Atwood's extensive back catalogue includes a group of fictive autobiographies, each engaged in a self-reflexive consideration of the problems involved in writing a life story. These fictive meta-autobiographies consciously critique any act of self-representation within narrative in a radical challenge to phallogocentric models of life-writing and truth-telling. This group of texts (including Cat's Eye [1988], Lady Oracle [1976], The Handmaid's Tale [1985], and The Blind Assassin [2000], as well as some of Atwood's poetry) also incorporates a dominant use of visual images, particularly photographs: each extending questions involving the "real," the "copy," origination, attribution, and authority. These questions open up new ways of considering how text and image conspire to defer certainty in the objective and subjective "real," as Atwood's visual texts prove to be as duplicitous as the language through which they are narrated. This article connects with critical accounts of lifewriting and with Susan Sontag's reflections on photography in order to discuss the status of the visual image as an agent of representation within any autobiographical account.
\end{abstract}

Biography and autobiography are vexed issues within critical discussion, whether in the traditional or in the fictive mode. Critics including Shari Benstock and Paul de Man have argued that self-representation in text is a logically impossible enterprise, not least because (like historical narrative, with which it has much in common) it takes place within the unstable field of discourse. Further, autobiography involves a willed agenda: there is a "reading" of the past informing the act of narration, which so often in Atwood's prose, is fueled by a drive toward exoneration or confession. In addition, because "the past becomes its representations," there is much invested in the desire to authorize that through which "the past" will be known (Michael 92). Atwood's fictive autobiographers are canny, as well as uncanny, storytellers, acutely aware of the disturbance to "truth" that their authorship of "I" automatically involves, but compelled, nonetheless, to risk it when their survival depends upon bearing (self) witness.

The awkward question of "I" fuels several critical discussions of life-writing, and Atwood's autobiographers (Offred, Elaine, Joan, and Iris) each connect "I" with hesitation, fracture, and doubt. Even as they write or speak, the narratives they produce in the interests of selfrepresentation collapse as they stub their toes against one of the crucial problems involved in the autobiographical act - that is, which "I" is writing and which "I" is written about. Shari Benstock asks:

where does one place the "I" of the autobiographical account? Where does the Subject locate itself? In definitions of autobiography that stress self-disclosure and narrative account, that 
posit a self called to witness (as an authority) to "his" own being, that propose a double referent for the first-person narrative (the present "I" and the past "I"), or that conceive of autobiography as "recapitulation and recall," the Subject is made an Object of investigation (the first-person actually masks the third person) and is further divided between the present moment of the narration and the past on which the narrative is focused. (1047)

Several of the issues Benstock raises in relation to life-writing are invaluable in reflecting upon Atwood's use of fictive autobiography within the fictional frame. Both traditional autobiography and fictive autobiography do essentially the same thing: both "write" a "life," and even in traditional autobiography, the construction of the subject (who becomes a type of omniscient narrator because s/he is equipped with retrospective knowledge) is an act of fiction anyway. Paul de Man, for example, detects a fraud when he states that autobiography "seems to depend on actual and potentially verifiable events in a less ambivalent way than fiction does" but "seems" opens up a world of doubt as to the viability of the distinction between the two (920). The construction of the past-tense self depends on precisely the type of framing associated with fiction, since the "past" self is a compendium of perspective, distortion, and desire. But where conventional life writers work toward a seamless unification between the "double referent," connecting "the present 'I' and the past 'I," so that the gap between the two is effaced, Atwood's female storytellers work away from unity and thus splinter the coherence of the subject position. In so doing, they demonstrate de Man's argument that the implied autobiographical revelation of "reliable self-knowledge" is at best a "figure of reading" (921) and at worst a complex hoax (922).

Each of the life-stories discussed here is generated by their narrators' implied or explicit desire to reclaim narrative ownership and to set the record straight. Atwood's writers, however, quickly realize that all they can hope to do within narrative is to offer a provisional construction, and the possibility of presenting the definitive version of events or of themselves gradually assumes the status of a lost cause. In The Handmaid's Tale (1985), for example, Offred is trapped within Gilead, a totalitarian theocracy where resistance is ruthlessly punished. Offred's only hope for survival is compliance, but this relies on a burial of her former identity (unearthed in the quiet spaces of "Night") and the production of a new one as a Handmaid. In pondering this situation, Offred's use of the word compose begins to acquire alternative implications: "I compose myself. My self is a thing I must now compose, as one composes a speech. What I must present is a made thing, not something born" (Handmaid's Tale 76). Ostensibly, Offred is referring here to the need to "compose" herself as a Gileadean Handmaid: in what is revealed to be a type of performance, she must selfpresent as pious and submissive. But Offred means more than this alone: her statement connects narrative and composition via "speech" so that "myself" becomes a conscious staging. Just as one "composes a speech" (and her oral narrative is an extended "speech" to the future), she must also "compose" "self." In making a distinction between "a made thing" and "something born," she identifies Gilead's terrifying objectifying power: one is not born a Handmaid - rather, one becomes one. However, Offred's narrative as a whole articulates the sense that "self" must always be "composed," with or without Gilead, because the retrospective glance of life-writing, together with the imperatives of cultural performance, as conjoined with the devious potential of all discourse, makes "composition" inevitable. As Benstock notes, the subject converts herself into the "composed" object simply via selfrepresentation.

In Atwood's prose, the issue at stake will always return to tensions around the identity and role of the writer in whose hands power temporarily lies. An analysis of the interplay 
between verbal and visual framings within Atwood's meta-autobiographies reveals the extent to which these narratives consistently work away from seamlessness to challenge the integrity of self-representation. As a starting point, where Atwood's narratives involve autography, images are repeatedly used to disrupt any claim to secure identity construction. All such images are, of course, discursively accessed, so all only reference the visual field rather than belong unequivocally within it - they are examples of "photographic ekphrasis" and/or "phototexts" rather than physical artifacts (Barzilai 103, 105). As such, though we cannot "read" the images themselves, we can "read" the construction of them while remaining permanently aware that what is here configured as "visual" must always lie within the perimeters of the novels' language structures.

Notably, Atwood's fictive autobiographies usually contain descriptions of photographs that have been taken of the self-writer, and in each case, the image haunts and disturbs them. The photograph in question is often perceived as an attack, a threat, a painful shock to memory, a trigger to shame, or an allegory of unarticulated psychological rupture, and it always represents a troubled confrontation with a guilt-soaked and uncanny rendition of "I." The implication, however, that photographic images involve a painful recognition of "truth" is firmly contested in Atwood's work, which consistently disturbs the presumed contract between the image and the "real." Faith in this relationship is generally assumed, as Susan Sontag states in her well-known reading of the image, where a common belief in a secure relationship between photographs and "reality" is positioned: "Reality has always been interpreted through the reports given by images" she notes (153); "photographs are a way of imprisoning reality, understood as recalcitrant, inaccessible; of making it stand still" (163). As such, "the images that have virtually unlimited authority in modern society are mainly photographic images" (153).

However, while photographs are deemed to have a function as reporters, interpreters, and imprisoners of reality, Sontag then describes a rather more complex function; photographs, she notes, are "not so much an instrument of memory as an invention of it or a replacement" (165). In addition, to regard the photograph as a record of "reality" is, for Sontag, to make a serious error, since "photographs are as much an interpretation of the world as paintings and drawings are" (6-7). Atwood's use of photographic images in her fiction and poetry similarly insists on the vulnerability of the visual image in terms of its relationship with a secure truthbearing "reality." In "This is a Photograph of Me," for example, the photograph conceals rather than reveals the speaker: "I am in the lake, in the center / of the picture, just under the surface" (Eating Fire 2). We are told that "it is difficult to say where / precisely" (2) but that concentrated scrutiny will reveal her (or him): "if you look long enough, / eventually / you will be able to see me" (2). This is unlikely given that the photograph "seems to be / a smeared / print: blurred lines and grey flecks / blended with the paper" (2). However, that it only "seems to be" a "smeared print" troubles the status even of its own (un)readability, as does "the effect of water / on light" (2) because it produces "distortion" (2). This indeterminate image, compromised by its internal hesitations, is, therefore, willfully unhelpful in terms of telling the speaker's story because its main contribution to her/his narrative is to obscure it.

Similarly, "At the Tourist Centre in Boston" considers the gap between a tourist map of Canada, replete with glossy photographs representing each region, and the speaker's own memories of "my country" (Eating Fire 32). The two bear no relation to each other and again the photographic image moves away from a "report" of visual "reality" as the speaker's "private mirage" (32), though equally hesitant in its reality basis, achieves dominance. The 
photographs assume the compromised status of a "dream" or a "manufactured hallucination" (32). By the time we reach "Postcard," Atwood is clear in stating that there is a startling rift between the visual photographic image and the objective "reality" it purports to represent:

The palm trees on the reverse

are a delusion; so is the pink sand

What we have are the usual

fractured coke bottles and the smell

of backed-up drains, too sweet. (True Stories 18)

"Postcard" is unequivocal in situating the photograph as a simulation with nothing whatsoever to do with reality (however, that is understood). Far from even being a Platonic copy of the "real," it is in fact neither. In Steven Connor's summary of Victor Burgin's position, a related challenge to the integrity of the "framed" image occurs: "this pure and ineffable intelligibility of the image is an illusion, since all images, photographic or otherwise, operate in a dense network of relationship with other forms of representation, textual, visual and psychic" (97). This reading seems to be endorsed regularly in Atwood's work (The Blind Assassin [2000] and Cat's Eye [1988] provide plenty of potential examples, as discussed later), but equally there are instances of visual artifacts in her novels that seem to fundamentally trouble Burgin's faith that "intelligibility" is a possibility at all. The parody strewn Lady Oracle (1976) offers an apparently comic example of this when the confessional narrator, Joan, finds a photograph of her adored aunt in a booklet coyly titled "You're Growing Up." Joan is routinely enmeshed in webs of lies and identity frauds yet is always amazed to discover that everyone around her is similarly not who they seem to be. In Lady Oracle, the visual image becomes centrally involved in this perpetual game of charades, as the booklet demonstrates:

at the bottom of this page was a picture of Aunt Lou, smiling maternally and professionally, taken before her jowls were quite so large. Around her neck was a single strand of pearls. Although she did wear pearls in real life, it was never just one strand. Underneath the letter was her signature: "Sincerely yours, Louisa K. Delacourt." (85)

When Joan asks her about the letter in the booklet, Aunt Lou says, "I'm head of Public Relations, dear ... Just for Canada. But I didn't really write that booklet, you know. That was written by Advertising" (85). There are several issues in play here, all conspiring to interrogate representations of the "real": the photograph reworks Aunt Lou's image to diminish her "real" identity - Aunt Lou is typically excessive with her pearls "in real life," but constructed along less exuberant and more "maternal" lines in the photographic image. This image, then, distorts rather than "reports" "reality," as we realize when we splice the image with "other forms of representation" including the "textual." The increasingly shady image then combines with the signature and fraudulence doubles: the signature may or may not be Aunt Lou's (Joan notes that it is "her signature," but she may be referring to the implication within the frame rather than to "real life"), but in either case, she is clear that she did not write the text that it claims. In addition, the photograph represents Aunt Lou as she was ("before her jowls were quite so large", 85) but not as she is, so now the image, the text ascribed to her, and the signature that is attached to it, are all illusions within the visual 
frame. To compound the issues released here, furry, eccentric Aunt Lou is revealed in this passage to be a powerful PR executive (and even this doesn't provide the full story, for she is later revealed to be a woman of many other surprising parts), and Aunt Lou's signed name becomes Joan's pen name, so that it fraudulently claims text twice. The "intelligibility" of the image now looks woefully insecure, particularly in relationship with "other forms of representation," which muddy the waters further, and with that problematic signature that undermines what de Man terms the "legal" and implied "epistemological authority" that it seems to promise (922).

What Atwood offers in this passage is a hall of mirrors, wherein the verbal and the visual subvert each other, both colluding in the creation of illusion, and neither emerging as stable: de Man's doubts as to the potential disconnect between "the authenticity of the signature" and the identity of the "signee" move into sharp focus here (923), while Sontag's reminder that "the work that photographers do is no generic exception to the usually shady commerce between art and truth" (6), is fully confirmed. The example also fractures the idea that Atwood's prose operates through a type of "postcard" system of storytelling because, for meaning to emerge from an intersection between the word and the image ("Only that which narrates can make us understand," notes Sontag) (23), both must be capable of telling an at least partially secure (if incomplete) story. As the above example makes clear, this cannot be relied upon in these fictive meta-autobiographies, where the whole point is that both text and image, prone anyway to the vagaries of perspective and interpretation, cause hopes of representation to recede to a vanishing point. If even the "pure and ineffable intelligibility" of a photograph is "an illusion" (Connor 97), if "meaning" is produced via intersections with equally unstable discursive frameworks that conceal more then they reveal and distort more than they "report": there is no way to tell a "straight" story within representation.

The visual image in Atwood's novels is thus often as devious as text, and is often revealed to be as vulnerable as text to authorial agency. Laura's curious photographic adventures in The Blind Assassin are a case in point. Atwood's end-of-century novel weaves its complex narrative around two upper-class sisters, Iris and Laura Chase, whose life-stories are told through a collection of images and alternative narratives. As Magali Cornier Michael argues, "Iris can only represent her life in a fractured way; no single narrative exists that can include all the crucial aspects of her life" (88). However, this should not imply that epistemological confidence can be secured because "the combination of narratives" forms only "a textual version of Iris" (102): this "version" is only one of many potential versions, none of them definitive, and all inevitably marked by signs of autobiographical "masquerade" (92).

The boundary between the sisters' identities is dangerously blurred so that the defined "I" of Iris's initial is always under attack. This situation is staged within two important photographs, unpacked from Iris's steamer trunk, the first taken when Iris has just entered adolescence:

There's a studio portrait of Laura and me, taken at this time. I'm wearing the regulation dark velvet dress, a style too young for me: I have, noticeably, what used to be called bosoms. Laura sits beside me, in an identical dress. We both have white knee socks, patent-leather Mary Janes, our legs crossed decorously at the ankle, right over left, as instructed [. . .] Each of us has her light hair parted in the middle and pulled back tightly from her face. Both of us are smiling ...

(The Blind Assassin, 159-60) 
The twinning of the sisters is marked here ("identical," "both," and "each"), and it is little wonder that they end up as interchangeable as the "Peach Women of Aa-A" in the embedded science fiction narrative (The Blind Assassin 354). This merging of identities has devastating consequences for both Iris and Laura, and the threatening elision between them is again visually emphasized in the second crucial image, the Button Factory picnic photograph, which haunts the narrative and which provides a parallel version of the herstory produced by Iris. The resonance of the photograph is generated by its uncanny qualities, by its involvement in the "whodunnit?" and "elegiac memoir" textual levels (Barzilai 106), and by Laura's editorializing of the image to tell another kind of story altogether. Barzilai is entirely correct to note that this "frameless photo itself provides a frame for The Blind Assassin" (117).

Laura is the first to recognize the significance of the photograph of herself, Iris, and Alex Thomas taken at the picnic, and she smuggles herself into the town photographer's studio to prepare for its theft and to learn how to develop and hand tint photographic images. Her apprenticeship involves running riot with the family photographs and coloring various male figures (including several prime ministers) "delicate mauve," "bilious green," and "light crimson" (194). Here, Laura engages in a hybrid form of representation combining art and photography to express her view that the untouched image is concealing the true story. When challenged by Iris, Laura explains, "those men needed some enhancing," and she adds that the colors she has chosen correspond to the "colours of their souls ... It's the colours they ought to have been" (The Blind Assassin 194-95). Laura is here "making the latent manifest" in order to allow "the unseen to be seen" (Barzalai 115), but Laura's tinting simultaneously reveals the role of perspective in representation, because her tints are the equivalent of narrative editorializing: where Iris shades and highlights with words, Laura manipulates meaning using color on the visual plane. Crucially, though, photographic tinting looks artificial, so authorial meaning is rendered theatrically visible, and the advantage to Atwood here is that it reveals what is too easily missed in opaque, double-dealing prose. In addition, Laura's editing of the photographs involves her move from passive victim to active agent; this is a motive implicit in Iris's terminal writing project so that both sisters (twentiethcentury versions of Philomela and Procne) produce parallel texts - one verbal and one visual - each memorializing, malleable, and encoded, and each lethal - Richard/Tereus cannot survive the sisters' thirst for textual retribution.

Laura's aggressive editing of the haunting "picnic" photograph pushes matters a stage further. Laura presents Iris with a version of the photograph (developed from a stolen negative) of Alex with her sister. Originally, Laura was also in the image, but she has cut herself out; to avoid an uneven margin, she has had to retain her own disembodied hand at the edge of the picture. ("This is a Photograph of Me" had used the same device of an intrusion into the margins of the photographic image.) It seems that Laura would have retained this mark of her absence-presence anyway because in tinting it a pale yellow she has emphasized rather than concealed it. Iris is appalled by the "mutilated" photograph and asks Laura why she has produced it: "Because that's what you want to remember," responds audacious Laura (Blind Assassin 220). Such is the nature of photography and of autobiography: both are exercises in edited memory and fabrication, and Laura here reveals their contingency. To complicate matters further, Laura has created a second version of the photograph, this time cutting out Iris, but again leaving her hand visible at the edge of the image. Duplicated, edited, and with certainty fractured altogether, the photographs "mutilate" any objective record of the event and produce instead a choice of potential records that lie both outside and within the frame of the "frameless" image. 
When Iris finally reveals that she, and not Laura, wrote "The Blind Assassin" (yet another signature lacks "epistemological authority"), she returns to this photograph to explain the nature of the collaboration between them:

The real author was neither one of us: a fist is more than the sum of its fingers . . Laura was my left hand, and I was hers. We wrote the book together. It's a left-handed book. That's why one of us is always out of sight, whichever way you look at it. (Blind Assassin 513)

In other words, Laura literally and figuratively "had a hand" in the text, which, if we had looked more closely, we would always have been able to see. Just as Laura's photographic images require a careful spectator to seek out the story that the tinting and editing both reveal and conceal, so Iris's verbal texts require a scrupulous reader. What has not been included or recognized in the latter is precisely what is identified by Laura's hand-tinted and "mutilated" images. Atwood here demonstrates that both the photographic image and life-writing within narrative may make claims toward representational intelligibility, but both conversely fragment, split, and disorder the story that is told. Iris and Laura's spectral hands signifying conjoined absence-presence embed (or, perhaps, embody) a sharp reminder that life-writing demands attention not merely to what is there but more urgently to what is not.

Issues revolving around the interplay between the verbal and the visual are further extended in Cat's Eye, the novel that most slyly encourages the impression of secure meaning within the image/text relationship. Elaine Risley is a painter who has spent her career creating images that narrate in unreadable versions the trauma she suffered as a child at the hands of her friends, particularly Cordelia. Returning to Toronto for a retrospective exhibition of her work, Elaine tells her life story and simultaneously describes several of her paintings as she moves toward the locus of her trauma at the ravine. As with The Blind Assassin, Cat's Eye tells a sociocultural history within its first-person account, and a further connection with the later novel is its weight of visual images that seem to suggest that image and text collude to produce intelligibility. However, precisely the opposite reading emerges from a careful inspection of the photographs scattered through the novel, as this apparently unremarkable memory of a childhood snapshot makes clear: "I don't know who took that picture of me. It must have been my brother, because my mother is inside the cabin, behind the white door, wearing grey slacks and a dark-blue plaid shirt" (Cat's Eye 31). Here, words both describe the image and combine to produce ideas of space-time and memory. However, the image described cannot be as it is here verbally narrated because the photograph must have been in black and white, given the time frame. Elaine has added the color from memory and has thus produced a psycho-discursive version of Laura's "hand-tinting." This disturbs the relationship between word and image because the former does not accurately represent the latter, nor vice versa. Further, the "author" of the image is uncertain, prone to doubt. The image is thus contingent on three bases: firstly, it is not self-contained in its meanings, requiring memory (which is partial) to "hand tint" it; secondly, the image itself is unstable because it can be hand-tinted by memory (which may be faulty) and by language (which is approximate); finally, the image is unattributed and, therefore, lacks reliable authorship whoever took the photograph is unverifiable and, given that the photograph is here completed with memory, Elaine becomes the co-author of it anyway. The result is that the photograph loses all stability, in either its own terms or its relationship with the language that describes it.

Elaine sees a direct connection between photographs and her paintings, referring to both as "pictures," and repeatedly associating both with space-time. The paintings, like the photographs referenced in the text, are sub/versions of Stephen's scientific understanding of 
the universe and of her life story, and they function as encrypted snapshots of her repressed unconscious. A viewing of childhood photographs triggers the return of her memory when Elaine sifts through twice-buried "pictures" that have been shut away in a trunk and then stored away in an attic. Her mother is dying, and the retrospective she undertakes here causes memory to flood into her conscious mind so that she can state, "I see my life entire" (Cat's Eye 398). The second, finalizing "retrospective" occurs at "Subversions" gallery (named with appropriate irony) when Elaine reviews her "pictures" in another representational medium, one over which she has exercised authorial control: as she looks around her she sees another version of her "life entire" (398), displayed in chronological sequence despite her protests. All the faces and people from her past have been painted into the frame in ways she cannot interpret until now, but even here, despite the implicit claim that she is now seeing "straight," she interprets the canvases only in relation to her current positioning. Finally, she surrenders authority over meaning completely: "I can no longer control these paintings, or tell them what to mean" (409). A stable reading of her life story in whatever form can never be achieved because any representation is prone to editing, time, perspective, and interpretation. Here, the visual does not somehow "complete" the verbal, and the verbal does not somehow "explain" the visual: instead, both offer subversive commentaries on the futility of any attempt to achieve a coherent and unified representation of a life, regardless of the representational mode through which coherence is attempted.

An obvious enemy of unity and coherence is, of course, the unconscious, and Atwood's autobiographers generally spend a great deal of mental energy and textual space interrogating the meaning of what has been willfully buried or deliberately forgotten but that has come to light regardless: memory and desire meet bad conscience in most of these disturbing returns of the repressed. For Atwood's female storytellers, the inspection of old photographs always involves a painful confrontation with the ghosts that haunt them, so the framed image becomes associated with uncanny territory. Sontag notes that "all photographs are memento mori," and she indicates their participation in "another person's (or thing's) mortality, vulnerability, mutability" (15). Atwood responds to a similarly morbid sense of transcience in several of the photographs inspected by her fictive autobiographers: of the murdered girl in the ravine, Elaine notes the "haunted look" of her published photographs (Cat's Eye 241), and Iris Chase examines her wedding photographs and ponders the "effect of dappled light, falling not down on [Laura] but up" (Blind Assassin 240), this producing a spectral effect. The peculiarly eerie disembodied hand entering the edge of the "picnic" photograph belongs firmly in the same group of uncanny frames. However, in each case, eerie foreshadowing is only identified when the end of the story is known: Atwood's biographers interpret the image using hindsight, and this changes what they see. As Sontag argues, "when the notion of reality changes, so does that of the image, and vice versa" (160).

Iris's hindsight in re-viewing her wedding photographs converts her own former identity as the framed young bride into an "uncanny stranger on display" (Cixous 337). She marks this rupture between past and present selves by referring to her younger incarnation in the third person, simultaneously indicating her marginal claim to existence by providing a new frame for her in the form of parentheses:

(I say "her" because I don't recall having been present, not in any meaningful sense of the word. I and the girl in the picture have ceased to be the same person. I am her outcome, the result of the life she once lived headlong; whereas she, if she can be said to exist at all, is composed only of what I remember. I have the better view - I can see her clearly, most of the time. But even if she knew enough to look, she can't see me at all.) (Blind Assassin 239) 
The problems of writing autobiography again move into sharp focus here, because how can such sharply distinct identities be unified? As Benstock asked, "where does one place the "I" of the autobiographical account?" and how can "the present 'I' and the past 'I" find a stable subject position? (1047). As far as Iris is concerned, there are (at least) two of her; the young Iris who is memorialized in the frame is an emptied-out shadow figure who has receded with time and been superseded by an alternative person. Only the "later" Iris "can see her clearly" because she has retrospective vision (at least, she believes that she has - her qualifying "most of the time" suggests her own level of doubt in this regard). The framed, trapped, objectified "girl in the picture" is a sitting duck, and is at a distinct disadvantage since she cannot "see" old Iris who is the "outcome," or the end of the story. Like Cordelia in Cat's Eye, young Iris now has only a "tendency to exist" (112) because her composition depends entirely on the invested, selective distortions of memory. Iris does not attempt to evade this ("[she] is composed only of what I remember") and her "insight" torpedoes the autobiographical project, once again in complicity with the photographic image.

Repeatedly in Atwood's fictive autobiographies, the writing subject uses photographs as Iris does: to reflect on the gap between past and present identities. In Cat's Eye, the young Elaine Risley views a photograph of herself taken only one month earlier and notes, "Already that child seems much younger, poorer, farther away, a shrunken, ignorant version of myself" (55). In such cases, the photographic image ruptures the coherence of identity entirely ("myself" is here distanced from "that child") and raises fresh doubts around the possibility of writing a life defined by mutability. The central problems of life-writing are enshrined here: a "life" needs retrospection in order for it to be written, but retrospection inevitably distorts the text. Further, by the time writing occurs, the "self" as it was known has long since departed and has been replaced by multiple and shifting compositions based on what is remembered. In other words, space and time deal a fatal blow to the life-writing project even before the hopeless problem of converting a life into words is involved. Photographs prove capable in Atwood's fiction of centralizing these disabling problems because they so often expose the fragility of the reconstructive, retrospective gaze, and they reveal the conditional nature of subjectivity where "I" becomes past tense even as it is written.

Equally, there are instances in Atwood's fiction where past and present identities are more continuous than the fictive autobiographer would wish, and in these cases, photographs become a feared, dangerous body of evidence. In Lady Oracle, the threat to Joan's security resides within the photographic image; Joan is permanently in flight from her "fat child" self and she wears the guilt and shame she associates with this identity like an albatross around her neck. She has created a new version of her life and of her story, one in which she is glamorous, successful, and untroubled by either a traumatic childhood or excess flesh. The problem, however, is that fat-child Joan did exist (and still does), and there is photographic evidence to prove it. In this image, for example, the "real" Joan is squarely center frame:

I'd devised an entire spurious past for this shadow on a piece of paper, this woman of no discernible age who stood squinting at the camera, holding a cone of pink spun sugar, her face puffed and empty as a mongoloid idiot's: my own shucked-off body. (Lady Oracle 91)

Joan claims this shadow-woman to be "Aunt Deidre" (91), and she fabricates an entire history for her: here words undermine the truth-bearing potential of the image where Joan is hidden in plain sight. This reveals a pattern in Atwood's fiction, where evidence is presented within the visual frame but passes undetected. In "This is a Photograph of Me," precisely the same situation occurs; the speaker is in the frame but cannot be seen ( $\mathrm{s} / \mathrm{he}$ is beneath the 
surface of the lake). "At the Tourist Centre in Boston" also indicates the presence of an unseen presence: "Do you see nothing / watching you from under the water?" (Eating Fire 32). In much the same way, Laura enters the frame in Iris's photograph but she is not identifiable unless we know she is there. In all cases, the image exposes the "true" story (or some of it, at least), but we have to know what the story is before we can see it. As before, "when the notion of reality changes, so does that of the image, and vice versa" (Sontag 160). If the story is not already known, the visual image is not capable of revealing it.

The fact that "exposure" is part of photographic vocabulary is interesting here, not least because in these examples, "exposure" is precisely what the image both does and does not do. Atwood consistently undermines the notion that the visual frame does not lie but her storytellers are unwilling to risk it. Because they can "see" the story revealed yet simultaneously hidden within the image, they fear that it is equally available to all spectators. They avoid having their photograph taken if they can because to be "shot" is to become vulnerable; to surrender their own framing risks "exposure," risks placing evidence in other's hands, and risks surrendering the construction of identity to another. If, as Sontag notes, "To photograph is to appropriate the thing photographed" (4), then to be trapped in the frame is to become the "appropriated" "thing" itself. There is a connection here between the framed female image and her position within the cultural and economic matrix, a position often noted by Atwood in her work. As she states in her vicious prose poem, "The Female Body" (Good Bones 43-51), the woman's image is used as a commodity in order to sell other commodities to the point where it becomes fetishized. The woman is passive and defenseless in this role, her power surrendered to anonymous sets of profit-based interests. The use of the "framed" and commodified female is of critical interest to feminist film theorists, whose debates about the appropriated image prove relevant here. Laura Mulvey's seminal essay, "Visual Pleasure and Narrative Cinema," argues that the audience's gaze upon the female image is scopophilic within Freud's formulation of the term. Mulvey explains that Freud "associated scopophilia with taking other people as objects, subjecting them to a controlling and curious gaze" (836). The lack of authority and agency this gestured towards is significant since this seems to be precisely what Atwood's photographed autobiographers react against: when they are "subjected to" the gaze of others (and of their own later selves), they surrender their subjectivity and become "objects," as the spectator gazes upon their image with scopophilic "curiosity." Clearly, this has implications on a wider scale because it both enacts and perpetuates the disempowered position of women within patriarchal culture. Mulvey locates the scopophilic framing of women that lies at the heart of a sexually imbalanced world:

pleasure in looking has been split between active/male and passive/female. The determining male gaze projects its phantasy onto the female figure, which is styled accordingly. In their traditional exhibitionist role women are simultaneously looked at and displayed, with their appearance coded for strong visual and erotic impact so that they can be said to connote tobe-looked-at-ness. Woman displayed as sexual object is the leitmotif of erotic spectacle. (838)

The screen-shot of what may (or may not) be the child Oryx in Oryx and Crake (2003) obviously offers a clear demonstration of this "erotic spectacle" and further confirms Sontag's argument that "there is an aggression implicit in every use of the camera" (7). Notably, in Atwood's novels it is usually men who take the photographs and women who are framed within them. Elwood, for example, "shoots" the resonant image of the sisters with Alex (though it is Laura who is later responsible for its crucial editing, just as all of Atwood's writers "edit" dominating male compositions). To photograph, then, becomes an issue of 
power: though "the camera doesn't rape, or even possess [. . . ] it may presume, intrude, trespass, distort, exploit" (Sontag 13). It is not a matter of the camera itself, however, but of the motivation of the photographer, whether that is scopophilic, memorializing, appropriative, or a combination of these and associated impulses. Thus, there is "something predatory in the act of taking a picture" (Sontag 14), even pornographic (Sontag 13-20). Certainly, this message has been drilled into the Handmaids:

Modesty is invisibility, said Aunt Lydia. Never forget it.

To be seen - to be seen - is to be - her voice trembled -

penetrated. What you must be, girls, is impenetrable.

She called us girls. (The Handmaid's Tale 39)

Thus, when a group of what seem to be Japanese tourists block their path and ask to take their "picture," Offred and Ofglen turn their heads away and gesture "No. What they must see is the white wings only, a scrap of face, my chin and part of my mouth. Not the eyes" (38). Gilead forbids it of course ("must"), but Offred's alarm is suffused with other responses here: if she is unable to enjoy full vision (the wings prevent it, and there are no mirrors available to her in Gilead), why should these "Westernized" tourists, "their very cheerfulness aggressive" (38), feast on her image, an image that she herself is forbidden to see? This tense scene demonstrates the way in which Gilead has proved adept in recalibrating its citizens' vision, so that the "freedom" of Western dress now looks to the staring Offred and Ofglen "blatant" and "undressed" (38), and adept also in using perceived violations of women to justify violating them in new ways. To be free of the "predatory" camera is here to be trapped by infantilized silence and "invisibility": as so often in Atwood's fiction, there is no way of winning if you are a woman.

Grace Marks, however, understands this situation better than most of Atwood's protagonists. Alias Grace (1996) is not a fictive autobiography, but sections of first-person testimony are twined through the omniscient narration. In her reminiscences, Grace recalls being the object of the scopophilic male gaze throughout her life, for example, when spied upon through a telescope (another type of lens) by Peeping Tom Kinnear. Grace recognizes the perverted nature of this when she compares his actions to "looking through the keyhole" (Alias Grace 305). But her history reveals other types of erotic framing too, including the engraved image that was made of her during her trial. This portrait of Grace implies pre-photographic representational verisimilitude, and its apparent aim is to produce a likeness of the girl accused of a double murder in order to satisfy the curiosity of an enthralled public. Simon Jordan is the young doctor on a mission to save Grace, or at least to penetrate her one way or another, and his first introduction to his patient is via her engraved image. He immediately realizes that it has been generated by the demands of the prurient narrative constructed around Grace rather than by the "reality" of her:

At the front is an engraved portrait of Grace, which could easily pass for the heroine of a sentimental novel; she'd been just sixteen at the time, but the woman pictured looks a good five years older. Her shoulders are swathed in a tippet; the brim of a bonnet encircles her head like a dark aureole. The nose is straight, the mouth dainty, the expression conventionally soulful - the vapid pensiveness of a Magdalene, with the large eyes gazing at nothing. (67) 
Grace's image is testimony to Sontag's point concerning the interpretive compulsion of artwork: "What is written about a person or an event is frankly an interpretation, as are handmade visual statements, like paintings and drawings" (4). The image clearly bears no relation to Grace: the emptiness of the gaze that is emphasized here is particularly notable because it contrasts so sharply with the "wide-eyed awake and watchful" (79) penetrative gaze that Grace attributes to herself. The "reality" of Grace, then, floats free of the visual representation of her, and the portrait comes to endorse Budd Boetticher's assertion that "What counts is what the heroine provokes, or rather what she represents . . In herself the woman has not the slightest importance" (Mulvey 838). In this transaction, Grace is converted from a subject position that emphasizes her youth ("she'd been just sixteen") into a mature, sexual object ("the woman pictured"). Though Simon Jordan seems to resent this here, he is equally prone to producing objectifying "pictures" of Grace that position her as the damsel in distress to his noble rescuer:

The morning light fell slantingly in through the small window high up on the wall, illuminating the corner where she stood. It was an image almost mediaeval in its plain lines, it angular clarity: a nun in a cloister, a maiden in a towered dungeon, awaiting the next day's burning at the stake, or else the last-minute champion come to rescue her ... But then Grace stepped forward, out of the light, and the woman he'd seen the instant before was suddenly no longer there. Instead there was a different woman - straighter, taller, more self-possessed. (69)

The arresting feature here involves the narration's reworking of the connection between light and "illumination," and between darkness and concealment: when Grace stands in a well-lit corner she seems to conform to Simon's crass, objectifying clichés ("a nun," "a maiden"), but when she moves "out of the light" (and presumably into dimness), "Grace" is revealed and she finally achieves a stable subject position. This does not stop Simon's quest to trap Grace within his own self-gratifying, erotic representations, but clever Grace knows this and always remains several steps ahead.

The case of the engraved image invites reflection on the relationship between the "real" and the "copy" in Atwood's work, a relationship also fundamental to debates concerning autobiography, and to discussions concerning the conversation between photography, art, and "reality" (see Sontag 153-80). Atwood's recurrent use of doubles and split identities consistently triggers tricky postmodernist questions about the status of "the copy" when "no authentic original" can be determined (Negotiating 44). Since autobiography is, to some extent, figured as a type of "copy" of the subject's life, this presupposes the existence of some kind of "authentic original," here defined as the subject's life. However, Atwood's fictive autobiographers challenge the authority of this logic and seem to suggest instead that the subject's life story and identity are actually formed by the autobiographical project in which the subject is engaged. As such, a situation arises in which we find a copy "imitating nothing [. . .] a ghost that is the phantom of no flesh, wandering about without a past, without any death, birth or presence" (Derrida 217). De Man makes a related point in less excitable terms when he suggests that, "the autobiographical project may itself produce and determine the life" (920). In other words, there is an argument to suggest that Elaine, Grace, Iris, and Offred make themselves up as they go along and that the alleged "original" life cannot be said to have existed until they do so. Justine Cassells states that, in Atwood's novels, "storytelling [is] a place where one decides who to be" (Stein 154), but the point may be pushed further to suggest that "to be" is only a concept until storytelling creates "the map that engenders the territory" (Baudrillard, cited in Poster 166). In this reading, the purportedly 
"real" or "original" (the writer's life) is symbiotically connected with the "copy" (the autobiography in composition), so that the former becomes impossible without the latter because they are symbiotically positioned. This is a relationship dramatically staged in The Blind Assassin, where the ink flowing through Iris's pen and the blood pumping through her heart are linked: here, body and text represent "life" and "writing" and they are as impossible to order into a hierarchy of antecedence as are "real" and "copy."

In Atwood's fictive autobiographies, then, the "copy" is centrally involved in the construction and the meaning of the "real" that it is only alleged to represent, and photography is repeatedly used to express this fraught dialogue. Just as photographs reveal gaps between the image (the copy) and the "reality" it purports to (and sometimes does) "report," and just as photography often identifies the tensions flowing around authority and authorship, so autobiography implicitly involves precisely the same knotty problems concerning origination, provenance, and power. Atwood makes such dominant use of photographs and images in her fiction because they economically challenge glib assumptions about the authority and transparency of the speaking "I" and because they expose the provisional economy of representation in any form.

Lying at the heart of the whole issue, of course, is the utter impossibility of life-writing within language and indeed of any act of self-representation. Benstock makes this point clear:

Language, which operates according to a principle of division and separation, is the medium by which and through which the "self" is constructed. "Writing the self" is therefore a process of simultaneous sealing and splitting that can only trace fissures of discontinuity. (1054)

The result is that autobiography reveals "the measure to which 'self' and 'self-image' might not coincide, can never coincide in language" (1044) or, in de Man's terms, the form "demonstrates in a striking way the impossibility of closure and of totalization (that is the impossibility of coming into being)" (922). Language will always block the emergence of coherence within self-representation, and Atwood marks this impasse via her fictional autobiographers who are unable to construct a self on which they (or we) can rely and which is continuous in its move through various past and present tenses. In this conflicted project, photographs and artworks do not recklessly construct a parallel text capable of accessing "Itruth": these careful postmodernist interrogations are far too nuanced to stake such a claim. Indeed, Sontag's appraisal of Plato's viewpoint provides a compelling summary of Atwood's own position in relation to the image-text-reality interplay. Plato, states Sontag, likens images to "shadows - transitory, minimally informative, immaterial, impotent co-presences of the real things which cast them" (Sontag 179-80). In Atwood's duplicitous novels, where visual images and narration throw radical doubt on the status of "I," what does not turn out to be a "shadow" of one kind or another, whether its "co-presence" is "real," "material," or not?

\section{Works Cited}

Atwood, Margaret. Alias Grace. Virago, 2004.

—. Cat's Eye. Virago, 1994

—. Eating Fire: Selected Poetry 1965-1995. Virago, 1995.

—. Good Bones. Virago, 1993.

—. Lady Oracle. Virago, 1992 
- Negotiating with the Dead: A Writer on Writing. Virago, 2003.

The Blind Assassin. Bloomsbury, 2000.

—. The Handmaid's Tale. Virago, 1995.

- True Stories. Oxford UP, 1981.

Barzilai, Shuli. "If You Look Long Enough: Photography, Memory and Mourning in The

Blind Assassin."Brooks Bouson and Graham, 2010, pp. 103-23.

Benstock, Shari. "Authorizing the Autobiographical.” Warhol and Herndl, 1988, pp. 104057.

Brooks Bouson, J., and Sarah Graham, editors. Margaret Atwood: The Robber Bride, The Blind Assassin, Oryx and Crake. Continuum, 2010.

Cixous, Helene. "The Laugh of the Medusa."Warhol and Herndl, 1976, 331-49.

Connor, Steve .Postmodernist Culture: An Introduction to Theories of the Contemporary. Blackwell, 1989.

de Man, Paul. “Autobiography as De-facement. ”Modern Language Notes, 94, 1979, pp. 919-30.

Derrida, Jacques. Dissemination. Bloomsbury, 2013.

Michael, Magali Cornier. "Narrative Multiplicity and the Multi-Layered Self in The Blind Assassin. "Brooks Bouson and Graham, 2010, pp. 88-102.

Mulvey, Laura. "Visual Pleasure and Narrative Cinema."1975. Film Theory and Criticism: Introductory Readings, edited by LeoBraudy and Marshall Cohen, Oxford UP, 1999, pp. 833-44.

Poster, Mark, editor. Jean Baudrillard: Selected Writings. Stanford UP, 1988.

Sontag, Susan. On Photography. Penguin, 1977.

Stein, Karen F. "Talking Back to Bluebeard: Atwood's Fictional Storytellers."

Margaret Atwood: Textual Assassinations - Recent Poetry and Fiction, edited by Sharon R. Wilson, Ohio State UP, 2003, pp. 154-71.

Warhol, Robyn R., and Diane Price Herndl, editors. Feminisms: An Anthology of Literary Theory and Criticism. Rutgers UP, 1991.

(C) The Author(s) 2017. Published by Oxford University Press; all rights reserved. For permissions, please e-mail: journals.permissions@oup.com 